\title{
TLR9 wt Allele
}

National Cancer Institute

\section{Source}

National Cancer Institute. TLR9 wt Allele. NCI Thesaurus. Code C96047.

Human TLR9 wild-type allele is located in the vicinity of 3p21.3 and is approximately $5 \mathrm{~kb}$ in length. This allele, which encodes toll-like receptor 9 protein, is involved in the modulation of signaling and the inflammatory response. 